\title{
Exceptionally well-preserved Orsten-type phosphatocopid crustaceans from the Cambrian of Poland
}

\author{
Ewa Olempska, Andreas Maas, Dieter Waloszek, and Mats E. Eriksson \\ Acta Palaeontologica Polonica 64 (1), 2019: 19-39 doi:https://doi.org/10.4202/app.00553.2018
}

Phosphatocopids are a group of small extinct marine crustaceans, which occur widespread in Cambrian dysoxic benthic lithofacies. Whereas the anatomy of the earliest ontogenetic stages of phosphatocopids, from the head larva with four pairs of appendages onward, is well documented, that of more advanced or adult growth stages has remained almost unknown (except for the external shields). Here we describe a three-dimensionally preserved specimen of a late growth stage of Cyclotron angelini from the Furongian strata ( 490 Ma) of northern Poland, which possesses six pairs of appendages (2nd-7th pairs; antennula missing), much of setation, sternum with paragnath humps, and the trunk end with the putative anus. Based on comparisons with known phosphatocopids, the cephalic feeding system of this late larva comprises the antennae with their gnathobase-like median structures on their syncoxa and the mandible with a likewise strong but oblique gnathic coxal endite. Both appendages have a short, specialized endopod bearing a prominent, dentate, stout median spine on its proximal portion. The antennulae are missing but, as in other phosphatocopids, they are not expected to have contributed to the feeding and locomotory system like they do in crustacean stem-lineage representatives and the Eucrustacea, especially in the early larval phase. The lack of an antennal exopod and strong reduction in size of the mandibular exopod of $C$. angelini suggest that these appendages had lost their function as locomotory and sweeping devices, in contrast to other phosphatocopids (and eucrustaceans). Therefore, they may have served mainly for food gathering in the vicinity of the mouth, which may represent an autapomorphy of this phosphatocopid species. Furthermore, in this developmental stage of $C$. angelini the production of water currents and movement of food particles toward the median food path was likely achieved by the large, paddle-shaped setiferous exopods of the serially developed post-mandibular limbs. For comparisons, we studied additional phosphatocopid specimens from the Dębki 2 borehole belonging to other taxa and representing different ontogenetic stages. This is also the first report of exceptionally preserved cuticular apodemes in phosphatocopids, extending internally and still bearing partly preserved, putative muscle bundles. As known from extant eucrustaceans, these apodemes most likely served as attachment sites for appendage muscles.

Key words: Crustacea, Phosphatocopida, Orsten-type preservation, phosphatization, apodemes, Cambrian, Poland. 
Ewa Olempska [olempska@twarda.pan.pl], Institute of Paleobiology, Polish

Academy of Sciences, ul. Twarda 51/55, PL-00-818 Warszawa, Poland.

Andreas Maas [maas.blaustein@freenet.de], Galgenackerweg 25, D-89134

Blaustein, Germany. Dieter Waloszek [dieter.waloszek@geol.lu.se] and Mats

E. Eriksson [mats.eriksson@geol.lu.se], Department of Geology, Lund University, Sölvegatan 12, S-223

62 Lund, Sweden.

This is an open-access article distributed under the terms of the Creative Commons

Attribution License (for details please see creativecommons.org), which permits unrestricted use, distribution, and reproduction in any medium, provided the original author and source are credited.

For Full text $(1,740.6 \mathrm{kB})$ 